\title{
Retinal changes in sickle cell/hereditary persistence of fetal haemoglobin syndrome
}

\author{
J. F. TALBOT, ${ }^{1}$ A. C. BIRD ${ }^{2}$ AND G. R. SERJEANT ${ }^{3}$
}

From the ${ }^{2}$ Department of Clinical Ophthalmology, Institute of Ophthalmology, Moorfields Eye Hospital, City Road, London ECIV 2PD; the ${ }^{1}$ Royal Hallamshire Hospital, Sheffield; and the ${ }^{3}$ MRC Laboratories (Jamaica), University of the West Indies, Jamaica

SUMMARY We describe for the first time retinal changes in sickle cell/hereditary persistence of fetal haemoglobin syndrome, which is a rare and benign disorder. The changes are qualitively similar to retinal disease seen with sickle haemoglobin and sickle $C$ haemoglobin, but are mild.

The syndrome resulting from the inheritance of both the sickle cell gene and the gene for hereditary persistence of fetal haemoglobin results in a syndrome called sickle cell/hereditary persistence of fetal haemoglobin (S/HPFH). It is a benign syndrome in which $25-35 \%$ of fetal haemoglobin ( $\mathrm{Hb} \mathrm{F}$ ) is distributed evenly throughout the red cell population with a marked inhibitory effect on sickling. As a result, accelerated haemolysis is unusual and symptoms attributable to vaso-occlusion rare. The clinical pattern of the syndrome is not well documented since it is uncommon, and no extensive reviews are available. ${ }^{1}$ There are no published reports on retinal findings in this condition, which is surprising, since the retinal vasculature would provide a sensitive indicator of whether vaso-occlusion occurs. Recently an opportunity has arisen to perform retinal examinations in 6 patients with S/HPFH and the results are presented.

\section{Material and methods}

The patients attended the sickle cell clinic at the University Hospital of the West Indies. Four patients aged 16-46 years were detected during family studies of relatives with sickle cell disease, and 2 patients (aged 8 years) were part of a cohort study of sickle cell disease followed up prospectively following diagnosis at birth. The diagnosis was based on major haemoglobin bands in the positions of $\mathrm{HbS}$ and $\mathrm{HbF}$ on haemoglobin electrophoresis under alkaline and acid conditions, low $\mathrm{HbA}_{2}$ levels, $\mathrm{HbF}$ levels greater than $20 \%$ and manifesting a relatively even intracellular distribution, and family studies where possible. Techniques of retinal examination were as previously described. ${ }^{2}$

Correspondence to Professor A. C. Bird.

\section{Results}

Some clinical and haematological details in the 6 patients are summarised in Table 1 . Retinal closure was present on angiography in 3 patients, and in one (case 2) there were other signs of sickle retinopathy.

In this patient visual acuity was normal in both eyes. Ophthalmoscopy revealed no abnormalities in the right eye, but in the left eye there was an irregular area of retinal pigment epithelial disturbance (sunburst spot) in the superotemporal periphery with an overlying vitreous capacity. An arteriole crossing

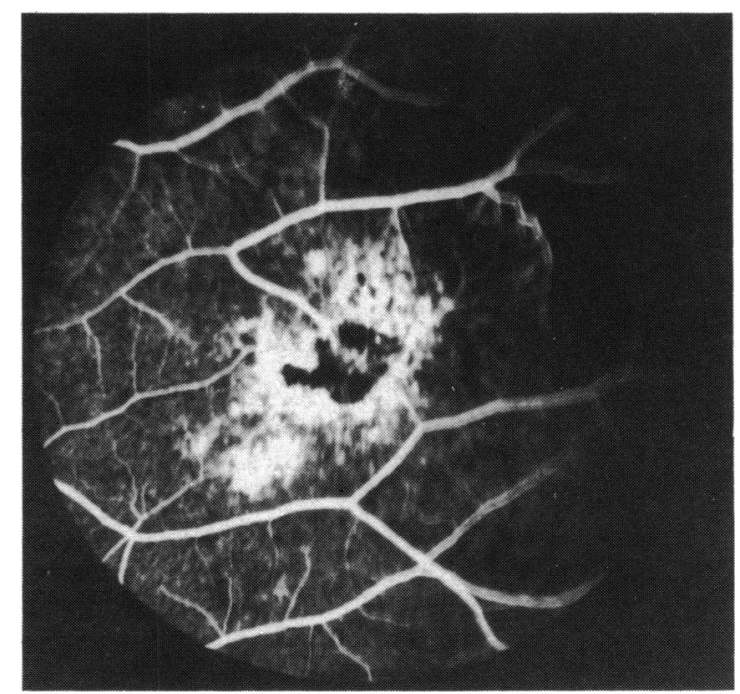

Fig. 1 Fluorescein angiogram of a sunburst spot in an 8year-old girl with sickle cell/hereditary persistence of fetal haemoglobin syndrome, showing a chorioretinal anastomosis. 
Table 1 Some details of haematological findings and retinal closure

\begin{tabular}{|c|c|c|c|c|c|c|c|c|c|}
\hline \multirow[t]{3}{*}{ Case } & \multirow[t]{3}{*}{ Age/sex } & \multirow{3}{*}{$\begin{array}{l}H b F \\
(\%)\end{array}$} & \multirow{3}{*}{$\begin{array}{l}H b A_{2} \\
(\%)\end{array}$} & \multirow{3}{*}{$\begin{array}{l}H b \\
(g / d l)\end{array}$} & \multirow{3}{*}{$\begin{array}{l}M C V \\
(f l)\end{array}$} & \multirow{3}{*}{$\begin{array}{l}\text { Reticulo- } \\
\text { cytes }(\%)\end{array}$} & \multirow{3}{*}{$\begin{array}{l}I S C s \\
(\%)\end{array}$} & \multicolumn{2}{|c|}{ Retinal closure } \\
\hline & & & & & & & & Right & Left \\
\hline & & & & & & & & \multicolumn{2}{|c|}{ (degrees included) } \\
\hline 1 & $8 \mathrm{M}$ & $31 \cdot 2$ & $1 \cdot 7$ & $12 \cdot 6$ & 76 & 3 & 0 & 0 & 0 \\
\hline 2 & $8 \mathrm{~F}$ & $30 \cdot 0$ & $1 \cdot 6$ & $13 \cdot 6$ & 71 & 2 & 0 & $60^{\circ}$ & $60^{\circ}$ \\
\hline 3 & $16 \mathrm{~F}$ & $34 \cdot 8$ & 1.9 & $14 \cdot 0$ & 80 & 1 & 0 & 0 & 0 \\
\hline 4 & $22 \mathrm{~F}$ & $25 \cdot 7$ & $2 \cdot 1$ & $11 \cdot 6$ & 79 & 3 & 0 & 0 & 0 \\
\hline 5 & $24 \mathrm{~F}$ & $27 \cdot 6$ & $2 \cdot 0$ & $12 \cdot 8$ & 74 & 2 & 0 & $90^{\circ}$ & $60^{\circ}$ \\
\hline 6 & $46 \mathrm{M}$ & $30 \cdot 4$ & $2 \cdot 1$ & $16 \cdot 2$ & 82 & 1 & 0 & Trauma & $60^{\circ}$ \\
\hline
\end{tabular}

this area appeared to terminate over it. Fluorescein angiography indicated this arteriole to be entering into a choroidoretinal anastomosis (Fig. 1). There were transmission defects at the site of the pigment epithelial disturbance, and capillary closure peripheral to the chorioretinal lesion. There was also capillary closure in the superotemporal quadrant of the right eye.

\section{Discussion}

Three of the 6 patients examined had evidence of peripheral retinal vessel closure, typical of sickle cell disease, and one had a sunburst spot, presumed to result from deep retinal haemorrhage ${ }^{3}$ through which an apparently spontaneous choroidoretinal anastomosis had developed. Although such anastomoses are common following photocoagulation therapy, especially with the xenon arc, ${ }^{4}$ spontaneous anastomoses are unusual and have only been described in one case of sickle cell disease. ${ }^{5}$

These findings suggest that, although the S/HPFH syndrome appears to run a very mild course, significant retinal vaso-occlusion may occur in this condition. This is compatible with other case reports which have detailed a variety of sickle cell related symptoms, including a mild haemolytic anaemia, ${ }^{67}$ splenomegaly, ${ }^{6}$ joint pains, ${ }^{8}$ avascular necrosis of the hip, ${ }^{89}$ and hemiparesis. ${ }^{9}$ However, the significance of these case reports is difficult to assess unless they are viewed against observations in a large representative sample of patients. Since most cases are asymptomatic and hence unlikely to present to medical attention, only by large-scale population screening would it be possible to define the medical abnormalities of such a group. Even this objective would be limited by the relative infrequency of the syndrome.
In a programme which screened 100000 consecutive cord bloods in Jamaica 6 cases have been currently diagnosed, usually by the finding of the trait for hereditary persistence of $\mathrm{HbF}$ (AF genotype) in one parent. A conservative estimate would suggest a prevalence of approximately 10 cases in 100000 , or 1 in every 10000 births. With such a low prevalence it would be desirable for retinal assessments to be made in all known cases, since these offer an elegant and sensitive method of detecting vaso-occlusion in a syndrome that could be an important model for learning more about sickle cell disease in general.

\section{References}

1 Serjeant GR. The clinical features of sickle cell disease. Amsterdam: North Holland Publishing Company, 1974.

2 Talbot JF, Bird AC, Serjeant GR, Hayes RJ. Sickle cell retinopathy in young children in Jamaica. Br J Ophthalmol 1981; 66: $149-54$.

3 Asdourian G, Nagpal KC, Goldbaum M, Patrianakos D, Goldberg MF, Rabb MF. Evolution of the retinal black sunburst in sickling haemoglobinopathies. $\mathrm{Br} J$ Ophthalmol 1975; 59: 710-6.

4 Condon PI, Serjeant GR. Photocoagulation in proliferative sickle retinopathy: results of a 5-year study. Br J Ophthalmol 1980; 64: 832-40.

5 Liang JC, Jampol LM. Spontaneous peripheral chorioretinal neovascularisation in association with sickle cell anaemia. $\mathrm{Br} J$ Ophthalmol 1983; 67: 107-10.

6 Went LN, MacIver JE. An unusual type of haemoglobinopathy resulting in sickle cell-thalassemia in a Jamaican family. Blood 1958; 13: 559-68.

7 Herman EC, Conley CL. Hereditary persistence of fetal hemoglobin. A family study. Am J Med 1960; 29: 9-17.

8 Jacob GF, Raper AB. Hereditary persistence of foetal haemoglobin production and its interaction with the sickle-cell trait. Br J Haematol 1958; 4: 138-49.

9 Conley CL, Weatherall DJ, Richardson SN, Shephard MK, Charache S. Hereditary persistence of fetal hemoglobin: a study of 79 affected persons in 15 Negro families in Baltimore. Blood 1963; 21: 261-81. 